\title{
A.Rakin, D.Garzetti DIFFERENT SIDEROPHORES CONTRIBUTE
TO THE HIGH-PATHOGENICITY PHENOTYPE IN YERSINIA
}

\author{
Max von Pettenkofer-Institute, LMU, Munich; Germany
}

\begin{abstract}
For successful proliferation in the hostile mammalian environments, the highly pathogenic Yersiniae (Y. pestis, Y. pseudotuberculosis and Y. enterocolitica subsp. enterocolitica) have to sequester ferric iron from the host iron storage molecules. Siderophores, low molecular weight molecules, that demonstrate high affinity for the iron, are responsible for $\mathrm{Fe}^{3+}$ capture and transport in bacteria. At least one endogenous siderophore system, yersiniabactin, is known to be involved in iron acquisition in highly virulent Yersiniae. Its inactivation in Y. pestis and Y. enterocolitica subsp. enterocoliti$c a$ results in significant attenuation of virulence. However, the yersiniabactin is not present in all highly virulent Yersiniae. Indeed, the large group of Y. pseudotuberculosis serotypes O2, O3, O4, O5 as well as serotype O1 Far East Scarlet like fever (FESLF) strains carry an alternative, iron acquisition system, pseudochelin, encoded by the Yersinia non-ribosomal peptide ynp locus. Thus, the yersiniabactin activity is not the only one associated with the high-pathogenicity phenotype of the human pathogenic Yersiniae.
\end{abstract}

Key words: pathogenic Yersiniae, high-pathogenicity phenotype, siderophores

\section{А.Ракин, Д.Газетти \\ Различные сидерофоры обусловливают фенотип высокой патогенности иерсиний}

\section{Институт Макса фон Петтенкофера, Мюнхен, Германия}

\begin{abstract}
Высоковирулентным Yersiniae (Y. pestis, Y. pseudotuberculosis и Y. enterocolitica subsp. enterocolitica) для успешного размножения в неблагоприятных условиях хозяйского организма необходимо трехвалентное железо, которое связано железосодержащими молекулами хозяина. Низкомолекулярные молекулы, сидерофоры, обладающие высоким сродством к железу, отвечают за эффективный захват и транспорт $\mathrm{Fe}^{3+}$ в бактериальную клетку. По крайней мере одна сидерофорная система, а именно, система синтеза и транспорта йерсиниобактина, отвечает за активный транспорт железа у йерсиний. Инактивация этой системы приводит к значительному снижению вирулентности у Y. pestis и Y. enterocolitica subsp. enterocolitica. Однако, йерсиниобактин присутствует далеко не у всех представителей рода йерсиний. Так, Y. pseudotuberculosis серотипов О2, О3, O4, O5, а также штаммы O1, вызывающие Дальневосточную скарлитиноподобную лихорадку, содержат альтернативную систему транспорта железа, псевдохелин, которая кодируется локусом упр (нерибосомный синтез пептидов). Следовательно, как минимум две системы снабжения железом ассоциированы с фенотипом высокой патогенности у йерсиний, а именно, системы йерсинибактина и псевдохелина.
\end{abstract}

Ключевые слова: патогенные иерсинии, фенотип высокой патогенности, сидерофоры.

The highly-pathogenic Yersiniae are defined as bacteria, which are able to kill mice in low infectious doses. Yersinia pestis, Y. pseudotuberculosis and Y. enterocolitica subsp. enterocolitica belong to this highly virulent group. Presence of the so-called High-Pathogenicity Island (HPI), encoding a siderophore yersiniabactin iron acquisition system (Ybt), is a main prerequisite for the high-pathogenicity phenotype in Yersinia. Loss or inactivation of this system results in significant virulence attenuation of $Y$. pestis and $Y$. enterocolitica subsp. enterocolitica $[3,5,7,11,14,15]$. Thus, the yersiniabactinmediated ferric iron uptake system is accepted as one of the main virulence-associated determinants in human pathogenic Yersiniae. However, although all highly pathogenic $Y$. pseudotuberculosis serotypes were initially suspected to possess the $y b t$ cluster this is not the case. It has been shown that only strains of serotype $\mathrm{O} 1$ possess the complete yersiniabactin gene cluster [15] while other highly virulent strains of serotypes $\mathrm{O} 2, \mathrm{O} 4, \mathrm{O} 5$ lack $y b t$. The situation becomes even more intriguing with strains of serotype O3, which partly contain the $y b t$ genes and partly are devoid of $y b t$. Moreover, the $y b t$ cluster is not functional in the $\mathrm{O} 3 y b t$ group, due to a partial truncation of the $y b t$ genes including the $f y u A$ gene encoding the yersiniabactin receptor $[9,15]$. Accordingly, the O3ybt strains are unable to produce the yersiniabactin, while the other $\mathrm{O} 3$ strains demonstrate siderophore activity on the chrome azurol S siderophore detection CAS agar [15, 19]. The O3ybt strains show also reduced virulence in animals compared to their siderophore positive counterpart $\mathrm{O} 3$ group [9]. Moreover, the strains of other highly virulent, human pathogenic Y. pseudotuberculosis serotypes, $\mathrm{O} 2, \mathrm{O} 4$, and $\mathrm{O} 5$, also produce siderophores in the absence of the yersiniabactin genes. Previously we have applied suppression subtractive hybridization to two serotype $\mathrm{O} 3$ strains of both groups (O3ybt and O3), the siderophorenegative Yp346 with a truncated $y b t$ and the prototype highly virulent siderophore-positive, but $y b t$-negative YPIII strain, widely used in Yersinia pathogenicity research [17]. Several gene sequences with high similarities to iron siderophore biosynthetic genes were uncovered in the YPIII genome (e.g. YPO0776, according to Y. pestis CO92 annotation). These data strongly support the presence of an alternative iron siderophore system 
in $\mathrm{O} 3$, a system that is able to substitute the $\mathrm{Ybt}$ and to support the high-virulent phenotype of Y. pseudotuberculosis. Indeed, sequence of the YPIII strain (http:// www.ncbi.nlm.nih.gov/genome/510?project_id $=59151$ ) demonstrated the presence of siderophore iron acquisition systems in the $\mathrm{O} 3$ group and the complete absence of the $y b t$ cluster. The functionality of at least some of these systems is supported by the ability of $\mathrm{O} 3$ strains to synthesize and produce a siderophore. In contrast, one of the potential alternative siderophore clusters, initially designated as HPI-2 (High-Pathogenicity Island-2, due to its similarity with the $y b t$ cluster located on a mobile HPI structure) is evidently non-functional in Y. pestis, due to insertion of the IS100 element, a frameshift disrupting the biosynthetic ORF and / or its disruption into two separated parts [8]. However, the HPI-2 cluster, designated ynp (Yersinia non-ribosomal peptide locus) is evidently intact in $Y$. pseudotuberculosis but entirely absent in Y. pestis Pestoides F strain. In Y. pseudotuberculosis serotype O1 IP32953 strain, the ynp locus (YPTB32903298) contains putative siderophore assembly genes (YPTB3296-3297) coding for the mixed nonribosomal peptide synthetase (NRPS) / polyketide synthase (PKS) pathway and transport genes (YPTB3290-3291) and TonB-dependent outer membrane receptor (YPTB3298) (Fig. 1). The ynp locus does not contain a phosphopantetheinyl (P-pant) transferase, which is necessary for the assembly of the NRPS-PKS complex. Therefore, one of the two P-pants encoded within the Yersinia genomes is necessary for the siderophore biosynthesis (Bobrov et al., 2002).

Here we aimed to look for distribution of the Yersinia pseudochelin Ynp system in Y. pseudotuberculosis with special impact on serotype $\mathrm{O} 3$ strains and address its possible implication in siderophore synthesis and iron uptake.

\section{Materials and methods}

Bacterial strains were obtained from the collection of the Max von Pettenkofer-Institute, LMU, Munich, Germany.

Siderophore production was demonstrated in a colorimetric chrome azurol S assay using a solidified liquid CAS agar developed by Schwyn and Neilands (1987).

Conditions of iron deprivation were achieved in NBD medium (Nutrient Broth, $5 \mathrm{~g}$ of $\mathrm{NaCl}$ with addition of 0,1 mM 2-2'-dipyridyl).

Primer walking was used to close the deletion gap in the $y b t$ cluster sequence in siderophore-negative but irp2positive $Y$. enterocolitica $\mathrm{O} 3$ genomes (O3ybt group).

A genome wide hybridization microarray [12] was applied to compare gene contents of the selected Yersinia genomes.

High-quality Y.pseudotuberculosis genome sequences were obtained from the publicly accessible databases http://www.ncbi.nlm.nih.gov and draft genome sequences of $Y$. pseudotuberculosis serotype $\mathrm{O} 4$ and $\mathrm{O} 5$ strains were obtained in cooperation with BGI-Hongkong Co. (Hong Kong) and annotated with the RAST server [2]. Circular representation of the genome comparisons was performed with BRIG [1].

\section{Results}

We have compared the strains of serotype $\mathrm{O} 3$ available in our collection (Table 1) for the presence of the yersiniabactin biosynthetic irp 2 gene and the ability to produce a siderophore on the CAS agar, to grow in irondeficient NBD medium and to support growth of E. coli H1884 entD, F (siderophore enterochelin -negative mutant unable to grow in iron depleted NBD medium). Only strains of the siderophore-positive $\mathrm{O} 3$ group, but not of the O3ybt group, were able to grow in iron depleted
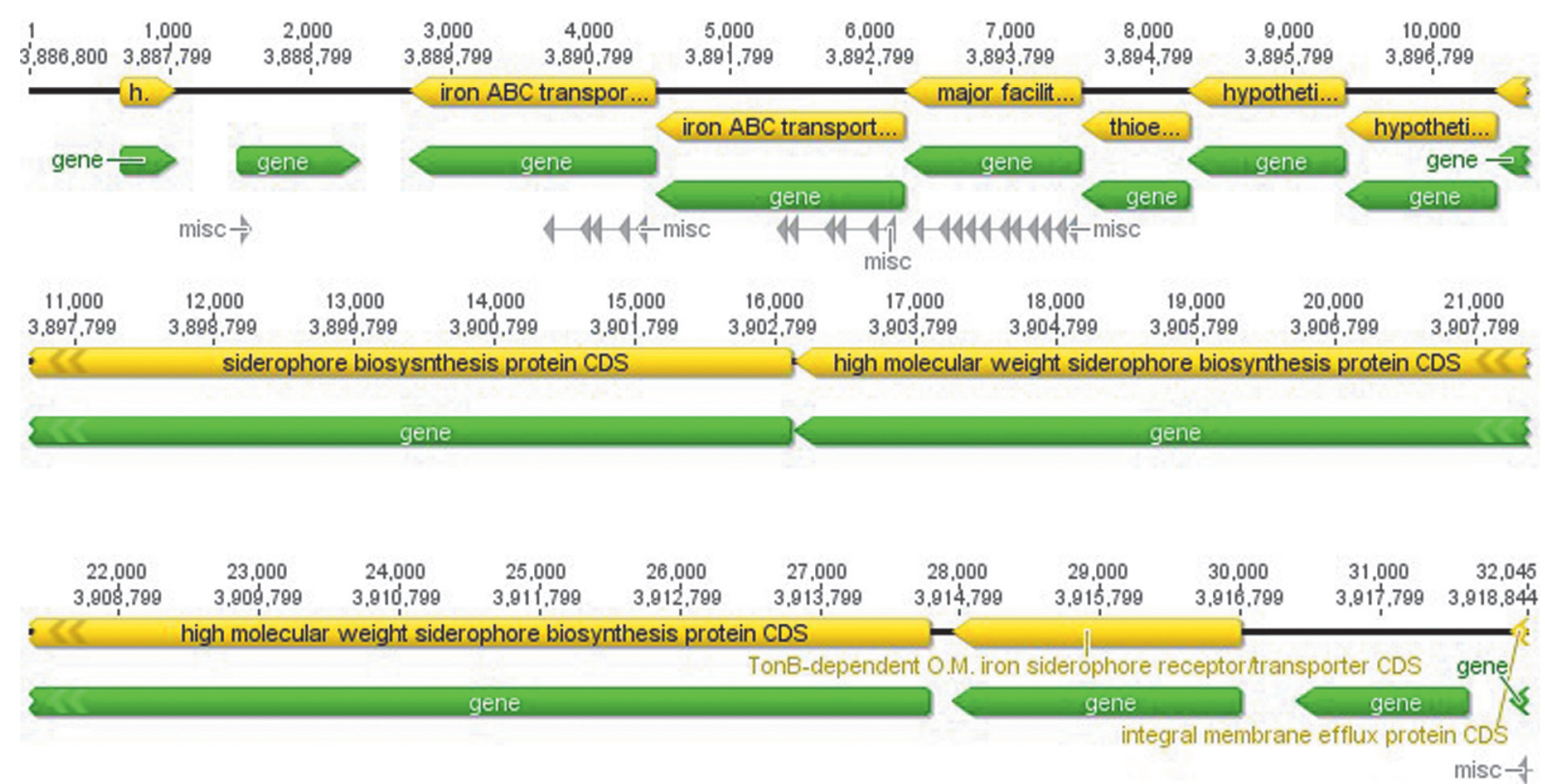

Fig. 1. The pseudochelin iron uptake operon (Yersinia non-ribosomal peptide locus ynp, YPTB3296-3297) in Y. pseudotuberculosis IP32953 strain (NCBI Reference Sequence: NC 006155.1). The picture is generated using Geneious program 6.1.5 
Table 1

Comparison of Y.pseudotuberculosis $\mathrm{O3}$ strains according to their CAS activity, presence of the $y b t$ genes and ability to grow and support

\begin{tabular}{|c|c|c|c|}
\hline $\begin{array}{c}\text { Strain, } \\
\text { isolation place }\end{array}$ & $\begin{array}{l}\text { CAS } \\
\text { activity }\end{array}$ & $\begin{array}{c}\text { Presence } \\
\text { of the irp2 gene }\end{array}$ & $\begin{array}{l}\text { Growth in NBD, } \\
\text { support of H1884 } \\
\text { ent } D, F \text { growth }\end{array}$ \\
\hline 1216/93, Norway & No & No & \\
\hline 14240, Turmenistan & No & No & \\
\hline 200/90, Germany & No & No & No \\
\hline 298/89, Australia & No & No & \\
\hline 1134/90, Japan & No & No & \\
\hline 2887, Argentina & No & No & \\
\hline Turku, Finland & No & No & \\
\hline Act-2, Russia & No & No & \\
\hline 307, New Zealand & No & No & No \\
\hline 346, Denmark & No & No & No \\
\hline 201/90, Germany & Yes & No & \\
\hline 201, Denmark & Yes & No & \\
\hline 1401, Sweden & Yes & No & \\
\hline YPIII, U.S.A. & Yes & No & \\
\hline 146 , Germany & Yes & No & Yes \\
\hline 445/73, Russia & Yes & No & Yes \\
\hline 483/71, Russia & Yes & No & Yes \\
\hline 714, Japan & Yes & No & \\
\hline
\end{tabular}

medium as well as to support the growth of the H1884 ent $D, F$ mutant.

Using the whole genome hybridization microarray [12] we tested the presence of the siderophore-associated sequences $(y b t$ and $y n p)$ in the $\mathrm{O} 3$ strains. It turns out that, while the strains of the O3ybt group contain the int, $y b t S-y b t P, y b t A$ and irp2-irp1 genes (YPO1911 YPO1916, according to Y. pestis CO92 annotation [13], they completely lack the $y n p$ genes (clustered in two groups, YPO0770 - YPO0778 and YPO1011 - YPO1012 in Y. pestis CO92, or YPTB3290-YPTB3298, according to IP32953 annotation). Alternatively, the O3 group siderophore-positive strains possess the complete $y n p$ gene clusters but none of the $y b t$ associated genes.

Using primer walking we have defined the deletion end point in the $y b t$ cluster in O3ybt strains (Fig. 2). The deletion includes $y b t U-f y u A$ sequences and terminates 30 bp downstream the irpl stop codon.

Several completed and draft Yersinia genomes are now available in the public databases (http://www.ncbi.

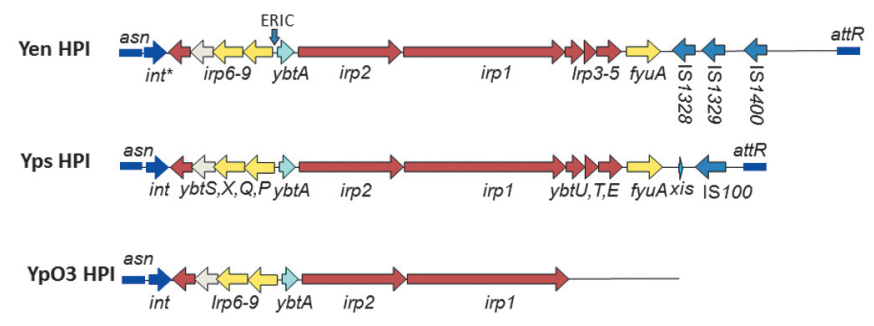

Fig.2. Structure of the yersiniabactin mobile gene cluster (HPI) in different Yersiniae. Note different designations of the $y b t$ genes in $Y$. pestis /Y. pseudotuberculosis. Yps HPI stands for Y. pestis HPI and YpO3 HPI - for Y. pseudotuberculosis O3ybt HPI and Yen HPI - for $Y$. enterocolitica subsp. enterocolitica HPI nlm.nih.gov/genome). For genome comparison we have included two draft genome sequences obtained from Y. pseudotuberculosis serotype $\mathrm{O} 4$ and $\mathrm{O} 5$ strains in cooperation with BGI, China. This allows analysis and comparison of the corresponding human-pathogenic Y. pseudotuberculosis for the presence of the siderophore iron uptake systems on the whole genome scale (Figure 3).

The partial deletion of the yersiniabactin $y b t$ gene locus is evident in serotype O3ybt strains B6796_O3, B6862 O3, B6863O3 and B6864 O3 while the complete $y \bar{b} t$ cluster is missing in strain YPIII serotype O3; strains $66, \mathrm{O} 4$ and 68, O5 and, to our surprise, also in the serotype O1 Far East Scarlet like fever (FESLF) strain IP31758 [6, 10]. Further sequencing of additional eight FESLF strains supports the absence of the $y b t$ genes in this group of serotype $\mathrm{O} 1$ strains (data not shown). In contrast, the $y n p$ cluster was absent in all O3ybt isolates but present in the strains of the other serotypes under comparison. Moreover, another potentially active siderophore iron acquisition system, aerobactin (iuc), is absent in the O3ybt strains. Thus, none of the three siderophores possibly supporting iron acquisition, the yersiniabactin, the pseudochelin (ynp) and the aerobactin (iuc) is present or functional in the O3ybt group. Interestingly, both iron uptake systems, ynp and iuc, are located in the integration hot spot that might represent another Plasticity Zone (PZ2) in Y. pseudotuberculosis genome. In contrast, sporadic Y. pseudotuberculosis $\mathrm{O} 1$ strains carry all three siderophore ferric iron acquisition systems. However, the functionality of these systems has to be demonstrated [8].

P-pant transferases are necessary for assembly of the NRP/PKS complex and synthesis of the pseudochelin. Indeed, all analyzed $Y$. pseudotuberculosis strains analyzed have both unaltered genes encoding P-pant transferases, $y b t D$, which initiates the YBT system and $a c p P$, required for the fatty acid synthesis. Thus, the two $\mathrm{O} 3$ groups do not differ by their ability to support the synthesis of the Ynp siderophore due to the absence of the supporting P-pants.

\section{Discussion}

The so-called High-Pathogenicity Island supplies bacteria with the ability to synthesize the yersiniabactin $(\mathrm{Ybt})$, a siderophore sequestering bound ferric iron from the host iron sources. The HPI represents an archetypical genetic mobile structure, a genomic island that transposes to any available free $a s n$-tRNA genes in the host genome using a site-specific recombination. The HPI originally described in Yersinia is widely disseminated in Enterobacteriaceae (20) due to its mobile nature. However, the Ybt system is not present in all highly pathogenic Yersiniae (as it was initially suspected) and it is restricted to Y. pestis and Y. enterocolitica subsp. enterocolitica, both of which demonstrate their absolute dependence on Ybt for in vivo survival and virulence [3, $5,7,11,14]$. 

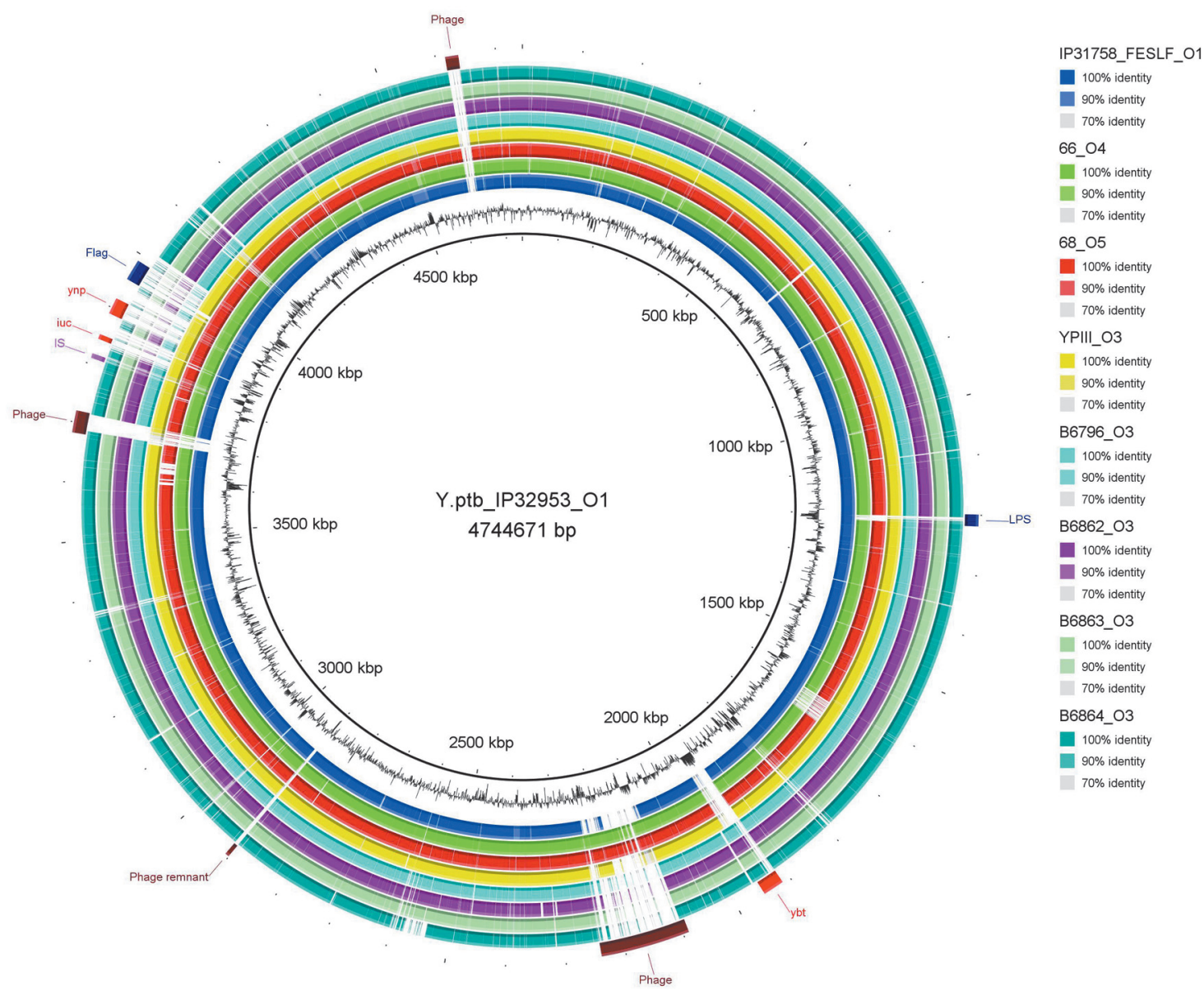

Fig. 3. Whole genome alignment of Y. pseudotuberculosis strains. Significant differentiating gene regions are represented. The white color indicates regions present in strain IP32953 but absent from the other strains

In contrast, most representatives of another group of highly virulent Yersinia, Y. pseudotuberculosis, do not possess the Ybt iron supply system. Only sporadic $Y$. pseudotuberculosis $\mathrm{O} 1$ strains demonstrate the presence of the $y b t$ gene cluster while strains of the other highly virulent serotypes, O2, O4, O5, as well as epidemic FESLF O1 strains, lack the $y b t$ genes. They also carry the pseudochelin $\mathrm{Fe}^{3+}$ acquisition system (Ynp) as an alternative to the yersiniabactin [18]. Moreover, serotype O3 strains likely exhibit competition between the Ybt and the Ynp ferric iron systems; they possess either of the systems, but not both of them. The similarity of the Ybt and Ynp systems and their potential biochemical and genetic cross talk might explain such competition of the two iron scavenging systems. Simultaneous presence and expression of these two related non-ribosomal peptide synthesized siderophore systems in sporadic $\mathrm{O} 1$ strains awaits its explanation.

Taken together, the alternative non-ribosomal peptide synthesized siderophore iron supply system Ynp (designated as "pseudochelin" due to its preferential distribution in Y. pseudotuberculosis [18]), is also responsible for the ferric iron siderophore mediated acquisition and, thus, for the highly-virulent phenotype of the vast majority of $Y$. pseudotuberculosis strains and serotypes. Indeed, inactivation of the siderophore biosynthetic gene YPBT3297 by homologous recombination with a chloramphenicol resistance cassette containing DNA fragment in YPIII, serotype O3 resulted in its inability to produce the siderophore (data not shown).

The ferric iron supply is not directly bound to pathogenicity of bacteria but it is a prerequisite for their successful multiplication in host and virulence potential. The Fur-dependent regulation of both iron supply and virulence supports a cross link between these traits. Bacteria, including pathogenic ones, possess different siderophore iron systems. Some of them have been acquired through a horizontal gene transfer and might be exposed in the available global gene pool and, thus, become available for import by other microorganisms to exploit alternative pathways.

\section{Summary}

1. The yersiniabactin ferric iron acquisition system, traditionally supposed to be responsible for the high-pathogenicity phenotype of Yersinia, is restricted to $Y$. pestis and Y. enterocolitica subsp. enterocolitica strains.

2. Human highly pathogenic Y. pseudotuberculosis $\mathrm{O} 2, \mathrm{O} 4, \mathrm{O} 5, \mathrm{O} 3 y n p$ and epidemic FESLF O1 demonstrate alternative siderophore activity in the absence of 
the yersiniabactin system.

3. The alternative iron acquisition system designated as pseudochelin (originally annotated as Yersinia non-ribosomal peptide locus, $y n p$ ) is responsible for the production of the siderophore in Y. pseudotuberculosis $\mathrm{O} 2$, O4, 05, O3ynp and FESLF O1 non-Ybt group.

4. Strains of two groups of Y. pseudotuberculosis $\mathrm{O} 3$, namely $\mathrm{O} 3 y b t$ and $\mathrm{O} 3$, demonstrate differences in their siderophore activity. Strains of the O3ybt group do not exhibit any siderophore activity and are of reduced virulence due to the absence of functional iron acquisition systems (the pseudochelin, ynp; the aerobactin, iuc and truncation of the yersiniabactin locus, $y b t$ ). In turn, the O3ynp strains are siderophore pseudochelin positive but lack the yersiniabactin locus, $y b t$.

5 . The present designation of the $y b t$ genomic island as the High-pathogenicity Island [4] as the only one associated with the high-pathogenicity phenotype in Yersinia is misleading and must be withdrawn.

\section{References}

1. Alikhan N.F., Petty N.K., Ben Zakour N.L., Beatson S.A. BLAST Ring Image Generator (BRIG): simple prokaryote genome comparisons. BMC Genomics. 2011; 12:402.

2. Aziz R.K., Bartels D., Best A.A., DeJongh M., Disz T., Edwards R.A., Formsma K. Gerdes S., Glass E.M., Kubal M., Mever F., Olsen G.J., Olson R., Osterman A.L., Overbeek R.A., McNeil L.K., Paarmann D., Paczian T., Parrello B., Pusch G.D., Reich C., Stevens $R$., Vassieva O. Vonstein V. Wilke A., Zagnitko O. The RAST Server: Rapid Annotations using Subsystems Technology. BMC Genomics. 2008; 9:75.

3. Bearden S.W., Fetherston J.D., Perry R.D. Genetic organization of the yersiniabactin biosynthetic region and construction of avirulent mutants in Yersinia pestis. Infect Immun. 1997; 65:1659-68.

4. Carniel E. The Yersinia high-pathogenicity island: an ironuptake island. Microbes Infect. 2001; 3:561-9.

5. de Almeida A.M., Guiyoule A., Guilvout I., Iteman I., Baranton G., Carniel E. Chromosomal irp2 gene in Yersinia: distribution, expression, deletion and impact on virulence. Microb Pathog. 1993; 14:9-21.

6. Eppinger M., Rosovitz M.J., Fricke W.F., Rasko D.A., Kokorina G., Fayolle C., Lindler L.E., Carniel E., Ravel J. The complete genome sequence of Yersinia pseudotuberculosis IP31758, the causative agent of Far East scarlet-like fever. PLoS Genet. 2007; 3(8): 142

7. Fetherston J.D., Kirillina O., Bobrov A.G., Paulley J.T., Perry R.D. The yersiniabactin transport system is critical for the pathogenesis of bubonic and pneumonic plague. Infect Immun. 2010; pathogenesis

8. Forman S., Paulley J.T., Fetherston J.D., Cheng Y.Q., Perry R.D. Yersinia ironomics: comparison of iron transporters among Yersinia pestis biotypes and its nearest neighbor, Yersinia pseudotu- berculosis. Biometals. 2010; 2:275-94.

9. Fukushima H. Molecular epidemiology of Yersinia pseudotuberculosis. Adv. Exp. Med. Biol. 2003; 529:357-8.

10. Gurleva G. G., Domaradskii I.V., Smolikova L.M., Khaliapina E.E., Grigor'ian E.G. [Biological properties of the causative agent of pseudotuberculosis isolated from scarlatina-like fever patients]. Zh. Mikrobiol. Epidemiol. Immunobiol. 1973; 50:125-9.

11. Heesemann J., Hantke K,. Vocke T., Saken E., Rakin A., Stojiljkovic I., Berner R. Virulence of Yersinia enterocolitica is closely associated with siderophore production, expression of an ironrepressible outer membrane polypeptide of 65,000 $\mathrm{Da}$ and pesticin sensitivity. Mol. Microbiol. 1993; 8:397-408.

12. Hinchliffe S.J., Isherwood K.E., Stabler R.A., Prentice M.B., Rakin A., Nichols R.A., Oyston P.C., Hinds J., Titball R.W., Wren B.W. Application of DNA Microarrays to Study the Evolutionary Genomics of Yersinia pestis and Yersinia pseudotuberculosis. Genome Res. 2003; 13(9):2018-29.

13. Parkhill J., Wren B.W., Thomson N.R., Titball R.W., Holden M.T., Prentice M.B., Sebaihia M., James K.D., Churcher C., Mungall K.L. Baker S. Basham D. Bentley S.D., Brooks K., Cerdeño-Tárraga A.M., Chillingworth T., Cronin A., Davies R.M., Davis P., Dougan G., Feltwell T., Hamlin N., Holroyd S., Jagels K., Karlyshev A.V., Leather S., Moule S., Oyston P.C., Quail M., Rutherford K., Simmonds M., Skelton J., Stevens K., Whitehead S., Barrell B.G. Genome sequence of Yersinia pestis, the causative agent of plague. Nature. 2001; 413:523-7.

14. Perry R.D., Fetherston J.D. Yersiniabactin iron uptake: mechanisms and role in Yersinia pestis pathogenesis. Microbes Infect. 2011; 13:808-17.

15. Rakin A., Urbitsch P., Heesemann J. Evidence for two evolutionary lineages of highly pathogenic Yersinia species. J. Bacteriol. $1995 ; 177: 2292-8$.

16. Rakin A., Schubert S., Pelludat C., Brem D., Heesemann J. The High-Pathogenicity Island of Yersiniae. In: Pathogenicity islands and other mobile virulence elements. Kaper J. B., Hacker, editors. Washington D.C.: ASM-Press; 1999. P. 77-90.

17. Rakin A., Golubov A., Iwobi A., Heesemann J. Tracing acquisitions and losses in Yersinia genomes. In: The Genus Yersinia. Entering the Functional Genomic Era. Skurnik M., Bengoechea J.A., Granfors K., editors. NY: Kluwer Academic/Plenum Publishes; 2003. P. 19-23.

18. Rakin A., Schneider L., Podladchikova O. Hunger for iron: the alternative siderophore iron scavenging systems in highly virulent Yersinia. Front Cell Infect. Microbiol. 2012; 2:151.

19. Schwyn B., Neiland J.B. Universal chemical assay for the detection and determination of siderophores. Anal. Biochem. 1987; 160:47-56.

20. Schubert S., Rakin A., Heesemann J. The Yersinia highpathogenicity island (HPI): evolutionary and functional aspects. Int. J. Med. Microbiol. 2004; 294:83-94.

Authors:

Rakin A., Garzetti D. Max von Pettenkofer-Institute, LMU, Pettenkofer str.9a, 80336 Munich, Germany. E-mail: rakin@mvp.uni-muenchen.de

Об авторах:

Ракин А., Газетти Д. Институт Макса фон Петтенкофера. Мюнхен, Германия. E-mail: rakin@mvp.uni-muenchen.de 